\title{
Deriving the International Rule of Law: An Unnecessary, Impractical and Unhelpful Exercise
}

\author{
Paul Burgess \\ Faculty of Laws, University College London, \\ Bentham House, 4-8 Endsleigh Gardens, UK, WC1H 0EG \\ paul.burgess@ucl.ac.uk
}

\begin{abstract}
The content of the international Rule of Law is frequently debated. In this debate, domestic Rule of Law conceptions are frequently—if only indirectly or implicitly—used to derive the international concept. I argue this derivation, and the debate regarding the form of any derivation, is unnecessary because the domestic conceptions frequently used as a foundation for the formulation of the international concept cannot be internationalised. This happens as the context in which such concepts were framed fundamentally differs to the contemporary international arena. I also argue deriving the international Rule of Law in this way is both impractical and unhelpful as derivation necessitates the arbitrary selection of aspects of domestic conceptions to formulate the international concept. I do not suggest there is not, or cannot be, an international Rule of Law. I do, however, argue the international Rule of Law should be formulated without recourse to domestic ideas.
\end{abstract}

\section{Key Words}

Conceptual Clarity; Context; Deriving; International Rule of Law; Rule of Law. 


\section{Introduction}

What is the international Rule of Law? What does it look like? And how can we identify it? The answers to these basic questions are not entirely certain. Some think they can be answered by internationalising the domestic conceptions of the Rule of Law; that the answers can be found by some form of derivative process. I take issue with this view. The domestic Rule of Law cannot be effectively internationalised as domestic conceptions' application beyond the state is limited by the fundamental differences that can be seen between the domestic and international Rule of Law contexts.

By reference to the historical, social, and political contexts in which the most commonly invoked domestic conceptions were formulated, I argue that deriving the international Rule of Law from domestic conceptions is unnecessary and, further, is both impractical and unhelpful. I do not suggest that an international Rule of Law cannot include desiderata that have previously been included in canonical Rule of Law conceptions. My point is, instead, much simpler. Given the absence of a domestic Rule of Law concept formed in relation to the same problems as those present in the international sphere, the rationale for using a domestic idea—or a modified version of that idea—as a foundation for the creation or identification of an international Rule of Law does not subsist. As those problems do not correlate, domestic Rule of Law conceptions should not be used as the foundation from which to derive an international Rule of Law. Whilst I do highlight two alternative methodologies and — albeit very briefly— expand these into a suggestion for a way forward, I do not propose an alternative international Rule of Law conception. Instead, by suggesting any meaningful conception of the international Rule of Law should be identified without deriving the same from the domestic conceptions, I seek merely to foreclose one aspect of the ongoing debate regarding the international concept's nature and content. 
Despite my somewhat negative position, I do not suggest the international Rule of Law does not exist. Any argument in these terms would fail to reflect reality. ${ }^{1}$ Bishop suggested a similar position in the " $60 \mathrm{~s}^{2}$ I do not disagree with him. The meaning, operation, and content of both the international and domestic Rule of Law concepts, however, remain contested. The concepts' natureas well as any link between them-also remains unclear. I attempt to bring some clarity to the debate regarding the international concept through advocating a course that makes the origins of statements regarding the nature of the international Rule of Law more precise. I do this by proposing that a common practice in the debate regarding the international concept should be discontinued. This common practice - of either directly or indirectly deriving the international Rule of Law from domestic conceptions - inherits much of the unclarity associated with the domestic concept and renders any attempt to use them as a foundation from which to derive the international conception both impractical and unhelpful. The practice should be discontinued in circumstances where the context in which domestic conceptions were proposed cannot reflect the context in which the international Rule of Law is thought to operate.

Derivation frequently plays a fundamental role in authors' positing the content, meaning, and nature of the international Rule of Law. A detailed critique, and more thorough explanation, of derivation will need to wait until Section 4 of this paper. However, for now, at this early stage, it is important to clarify what I take to be the broad form of derivation that I criticise. By derivation, I include any direct or indirect process of identifying a subsequent international Rule of Law account from a foundation of a domestic (Rule of Law) account. For reasons including the differing forms and objectives of the two (international and domestic) concepts, and in consequence of the generally accepted modifications that are required, few seek to explicitly and directly derive the international

\footnotetext{
${ }^{1}$ By 'reality' I mean to describe only the observable, and the broad idea '.. that almost all nations observe almost all principles of international law and almost all of their obligations almost all of the time.' Louis. Henkin, How Nations Behave: Law and Foreign Policy (2nd edn, Published for the Council on Foreign Relations by Columbia University Press 1979) 47.

${ }^{2}$ William W Bishop, 'The International Rule of Law' (1961) 59 Michigan Law Review 553.
} 
Rule of Law from the domestic Rule of Law; ${ }^{3}$ Hurd, for example, suggests the practice should be barred. ${ }^{4}$ Yet, it is clear that indirect or implicit derivation — through relying on the relative authority of prior canonical conceptions - remains prominent. The prior canonical conceptions are used as a sort of an argument from authority. Indirect derivation can take the form of the amendment or augmentation of pre-existing Rule of Law conceptions or through the identification of similar features in both domestic and international conceptions in order to add weight to a statement of what the international Rule of Law is. (These methodologies are expanded and illustrated in Section 4.) This can only result in unclarity. It also means that, in many of the contemporary statements regarding the international Rule of Law (that I explore below), canonical domestic accounts are used as a foundation and as a way to illustrate what the international conception is or should be because of the nature and or content of the domestic conception. It is because of the prominence of this broad indirect derivative practice that I seek to illuminate the problems that can arise.

The two arguments I make in pursuit of my point are interconnected. After briefly outlining the terms of the debate regarding the international and domestic Rule of Law in Section 2, I argue in Section 3 ('the argument from context') that the basic premise undergirding the derivation of the international Rule of Law - that domestic conceptions of the Rule of Law can provide a source from which it is possible to derive the international Rule of Law-is flawed; the premise cannot hold in terms where the contexts in which domestic conceptions were authored fail, in a number of ways, to reflect the context in which the international Rule of Law exists. By considering Rule of Law conceptions previously employed in relation to both the domestic and international spheres - in which domestic Rule of Law conceptions are treated as specific solutions to specific problems-I illustrate that the 'canonical' conceptions associated with the domestic Rule of Law cannot be usefully internationalised. I also demonstrate that, as a result, they should not play the foundational role in

\footnotetext{
${ }^{3}$ For one instance where the domestic idea is simply applied to the international context, see Robert E Goodin, 'Toward an International Rule of Law: Distinguishing International Law-Breakers from Would-Be LawMakers' (2005) 9 The Journal of Ethics 225. See also, Machiko Kanetake and André Nollkaemper, The Rule of Law at the National and International Levels Contestations and Deference (Hart Publishing Ltd 2016) 19.

${ }^{4}$ Ian Hurd, 'The International Rule of Law and the Domestic Analogy' (2015) 4 Global Constitutionalism 365, 367; Ian Hurd, 'The International Rule of Law: Law and the Limit of Politics' (2014) 28 Ethics \& International Affairs 39, 39-40.
} 
which they are frequently deployed in the international Rule of Law debate. I conclude Section 3 by finding that both derivation and the debate regarding the way in which the international Rule of Law should be derived - that I subsequently criticise in Section 4 ('the argument from origins')—is unnecessary.

Should my argument in Section 3 be wholly convincing, Section 4 could be seen as superfluous. Nevertheless, in Section 4, I identify and argue that two derivative methodologiesaggregated from a number of common approaches - regarding the meaning and content of the international Rule of Law are plagued by issues that render the enterprise both impractical and unhelpful by virtue of their inability to result in clarity of the international concept. In identifying the methodologies, I illustrate that arbitrary selection of aspects of domestic conceptions is necessary to facilitate this (flawed) process. In this regard, my point is somewhat simple: the necessary arbitrary inclusion of domestic conceptions' components in attempts to derive the international Rule of Law does not assist in identifying what the concept is or should be; derivation takes us no further than where we were prior to the start of the process. Finally, Section 5 offers some conclusions and briefly suggests a way to avoid the issues identified throughout the paper.

\section{The International and Domestic Rule of Law Debates}

In this section, I summarise the domestic and international Rule of Law debates. ${ }^{5}$ I do not intend to contribute to the various positions. I merely provide an overview of the ideas.

\subsection{The Domestic Concept Debate}

In the theoretical debates on the meaning and content of the concept of the Rule of Law, the concept could, regardless of whatever else it may be, be generally considered as relating to the imposition of

\footnotetext{
${ }^{5}$ From this point forward, I will use the Rule of Law to refer to the domestic concept. When referring to the international concept, I will use the slightly more cumbersome the international Rule of Law.
} 
a normative constraint upon the exercise of power. In less general terms, it has been suggested as being, if it is about anything, about the control of arbitrary power. ${ }^{6}$ Beyond this, whilst some suggest there is a common core to the Rule of $\mathrm{Law}^{7}$ there is little agreement regarding its precise content and it is often referred to as being an essentially contested ${ }^{8}$ or, at least, a deeply contested concept. ${ }^{9}$

In both the debate concerning the content and meaning of the concept, and the literature exploring its nature, a number of 'usual suspects' of the Rule of Law can be seen. This includes a number of 'canonical' writers whose theories are frequently associated with, or seen as constituent of, the Rule of Law. Their names will be familiar (and not just to anyone immersed in the literature that explores the Rule of Law's conceptual content): Aristotle, Hobbes, Locke, Dicey, Hayek, Fuller, and Raz to name but a few. Other similar lists have been described as 'a 'Who's Who?' of Western political thought... $\cdot{ }^{10}$ Each of these usual suspects' accounts differs - sometimes subtly, sometimes substantially - from one another. In this respect, it is trite to point out that the Rule of Law and its conceptions - even canonical ones - illustrate considerable variance; ideas of (what is currently considered to be) the Rule of Law have clearly varied greatly over time.

Such variance is specifically recognised in the Rule of Law literature. Not infrequently are these generalised differences specifically stated; for example, Todd Zywicki argues 'Dicey's

\footnotetext{
${ }^{6}$ This formed one of Dicey's desiderata, was important in Locke's ideas, and has also been attributed to Aristotle. John Locke, Two Treatises of Government (Peter Laslett ed, Cambridge University Press 1988) s §135; AV Dicey, Introduction to the Study of the Law of the Constitution (10th edn, Palgrave Macmillan UK 1979) 188-198 and 202-203; Aristotle, T Sinclair and Trevor J Saunders, The Politics (Penguin UK 1981) para $1287 \mathrm{aI}$.

${ }^{7}$ See for example, Brian Z Tamanaha, 'The History and Elements of the Rule of Law' [2012] Singapore Journal of Legal Studies 232. See also, Lisa M Austin and Dennis Klimchuk (eds), Private Law and the Rule of Law (Oxford University Press 2014) 1. Further examples, especially regarding the centrality of arbitrariness and the exercise of power, can be seen in Krygier's work: Martin Krygier, 'The Rule of Law: Legality, Teleology and Sociology' in Gianluigi Palombella and Neil Walker (eds), Relocating the Rule of Law (Hart 2009); Martin Krygier, 'Tempering Power' in Maurice Adams, Ernst Hirsch Ballin and Anne Meuwese (eds), Constitutionalism and the Rule of Law: Bridging Idealism and Realism (Cambridge University Press 2017).

${ }^{8}$ Jeremy Waldron, 'Is the Rule of Law an Essentially Contested Concept (in Florida)?' (2002) 21 Law and Philosophy 137; Richard H Fallon Jr, “"The Rule of Law" as a Concept in Constitutional Discourse' (1997) 97 Columbia Law Review 1, 7.

${ }^{9}$ Margaret Jane Radin, 'Reconsidering the Rule of Law' (1989) 69 Boston University Law Review 781, 781.

${ }^{10}$ Jørgen Møller and Svend-Erik Skaaning, The Rule of Law: Definitions, Measures, Patterns and Causes (Palgrave Macmillan 2014) 2.
} 
characterization of the modern content of the rule of law may be distinguished from the ancient "classical" conception of the rule of law, such as found in Aristotle. ${ }^{, 11}$ Whilst explicit reference is also often made to the change or difference in conceptions over time, ${ }^{12}$ some authors make explicit, yet more oblique, reference to historical differences; for example: Fallon states ' $[$ t] a much celebrated, historic ideal, the precise meaning of which may be less clear today than ever before. ${ }^{13}$ In this sense, conceptions of the Rule of Law that are separated by a millennia or more are frequently seen as reflecting the same idea or ideal; notwithstanding the fact that thinkers composing the usual suspects that predate Dicey's popularisation of the phrase 'the Rule of Law' in the late- $19^{\text {th }}$ century — as well as some authors after that date — generally did not use that phrase. ${ }^{14}$

A final and obvious superficial form of difference can be seen in the nature and content of the 'laundry lists' of desiderata that are offered in various canonical accounts. These vary

\footnotetext{
${ }^{11}$ Todd J Zywicki, 'The Rule of Law, Freedom, and Prosperity' [2003] Supreme Court Economic Review 1, 3. Shklar also contrasts and compares the specific differences between a number of historical conceptions in the opening paragraphs of her frequently cited work. Judith Shklar, 'Political Theory and the Rule of Law' in Allan C Hutchinson and Patrick Monahan (eds), The Rule of law: Ideal or Ideology (Carswell 1987) 1-3. (Zywicki, at note 5, references Shklar's work in relation to identifying the differences between the ancient and modern ideas of the Rule of Law.)

12 John P Reid, Rule of Law: The Jurisprudence of Liberty in the Seventeenth and Eighteenth Centuries (Northern Illinois University Press 2004) 3-4. This also extends to differences between conceptions at various points in the past; for example, Arndt specifically states Dicey's conception cannot be traced back to conceptual origins in the middle ages or, even, to Locke. See, for example, HW Arndt, 'The Origins of Dicey's Concept of the "Rule of Law" (1957) 31 Australian Law Journal 117, 117.

${ }^{13}$ Fallon (n 8) 1. Further, Krygier describes the impact of the differences in conceptions over time in this way: 'The rule of law is today more talked about in more places by more people than perhaps ever in its history, but that does not mean it is any clearer in meaning or significance, or better understood.' Martin Krygier, 'Inside the Rule of Law' [2014] Rivista di filosofia del diritto 77, 77. Krygier also suggests the concept's recent rise to prominence and the variety of conceptions results in it being 'rendered increasingly murky what the concept might mean, what the phenomenon might be, and why anyone should care.' Martin Krygier, 'The Rule of Law: Pasts, Presents, and Two Possible Futures' (2016) 12 Annual Review of Law and Social Science 1. For an illustration of the different historical approaches to Rule of Law conceptions, see the special issue, edited by Neil Walker and I, devoted to the operation and applications of the Rule of Law through history: Neil Walker and Paul Burgess (eds), 'Special Issue on the History of the Rule of Law' (2017) 9 Hague Journal on the Rule of Law.

${ }^{14}$ Terms like 'the empire of laws and not of men' had been invoked in the mid-seventeenth century and, arguably, before. Harrington paraphrases an Aristotelean sentiment in James Harrington, Harrington: 'The Commonwealth of Oceana' and 'A System of Politics' (JGA Pocock ed, Cambridge University Press 1992) 89. Jeremy Waldron, too, recognises this: 'It is sometimes said that Dicey in 1885 was the first jurist to use the phrase "the Rule of Law." I don't think that's true, except in the most pedantic sense of the exact grammatical construction.' Jeremy Waldron, The Rule of Law and the Measure of Property: The Hamlyn Lectures (Cambridge University Press 2012) 7. (Citation omitted.) The phrase was not used by Hobbes, Locke, or even Fuller, in their accounts. See Richard Tuck, Hobbes: Leviathan: Revised Student Edition (2 (Rev.), Cambridge University Press 1996); Locke (n 6); Lon L Fuller, The Morality of Law (Yale University Press 1964).
} 
considerably: Fuller's inner morality of Law lists eight, ${ }^{15}$ Raz lists a different eight, ${ }^{16}$ Hayek gives another-non-list based—formulation, ${ }^{17}$ and Radin offers two. ${ }^{18}$

Disagreement extends beyond the simple formulation of desiderata or their variation over time; it also relates to the concept's basic application and function. Whilst one important aspect of the debate relates to whether the Rule of Law should be applied in an international sphere, ${ }^{19}$ there are many other aspects. One that is frequently debated concerns whether the Rule of Law should be construed in formal or substantive terms. ${ }^{20}$ Formal terms relate to the processes of enacting a law ${ }^{21}$ and substantive terms relate to the inclusion of other considerations, including, for example, democracy, liberty, and freedom. Restricting an examination to formal criteria is not without merit, ${ }^{22}$ as it can avoid contaminating an examination ${ }^{23}$ or muddying of conclusions through the inclusion of additional features under the (substantive) Rule of Law umbrella term. ${ }^{24}$ For these reasons, ideas of democracy and human rights are frequently excluded in close conceptual analysis. ${ }^{25}$ Given the conceptual nature of my exploration, and despite the relevance of substantive ideas to the international sphere, I too limit my consideration to the formal aspects of the concept.

One of the few things that can be agreed on in the domestic debate is that there is not a precise and accepted meaning of the Rule of Law. This is the case in respect of its constituent desiderata, the extent of its reach, or even the purpose behind its existence. Consequently, substantial unclarity

\footnotetext{
${ }^{15}$ Fuller (n 14) 33-39.

${ }^{16}$ Joseph Raz, 'The Rule of Law and Its Virtue', The Authority of Law: Essays on Law and Morality (2nd edn, Oxford University Press 2009) 214-9.

${ }^{17}$ Friedrich A von Hayek, The Road to Serfdom (Bruce Caldwell ed, University of Chicago Press 2007) 112. Regarding the contested nature of various Rule of Law accounts, see Chapter 3.

${ }^{18}$ Radin (n 9) 786.

${ }^{19}$ Simon Chesterman, 'An International Rule of Law?' (2008) 56 American Journal of Comparative Law 331; Jeremy Waldron, 'Are Sovereigns Entitled to the Benefit of the International Rule of Law?' (2011) 22 European Journal of International Law 315.

20 Paul Craig, 'Formal and Substantive Conceptions of the Rule of Raw an Analytical Framework' [1997] Public Law 467. See also Brian Z Tamanaha, On the Rule of Law History, Politics, Theory (Cambridge University Press 2004) 91.

${ }^{21}$ See, for example, Raz's desiderata: Joseph Raz. Joseph Raz, The Authority of Law: Essays on Law and Morality (2nd edn, Oxford University Press 2009) 214-219.

${ }^{22}$ Charles Sampford, 'Reconceiving The Rule of Law for a Globalizing World' in Spencer Zifcak (ed), Globalisation and the Rule of Law (Routledge 2005) 19.

${ }^{23}$ Chesterman (n 19) 360.

${ }^{24}$ See Craig (n 20) 469. (Summarizing the argument made by Raz (n 21).)

${ }^{25}$ Tamanaha (n 7) 233-236.
} 
abounds. This, as the paper will address, has important ramifications to the debate surrounding the use of domestic ideas in relation to the concept's international formulation.

\subsection{The International Concept Debate}

The international debate is considered by many to be an extension of the domestic one. It is against this approach — the specific extension — that I argue and suggest, by way of a brief and simply put solution, the international concept should be defined and exist independently of the domestic concept. In effect, I indicate there is no necessary conceptual link between the two concepts.

Attempts to answer basic questions about the nature and content of the international Rule of Law are reflected in two aspects of the international debate. ${ }^{26}$ The first one relates to the role of states in the conceptual function of the international Rule of Law. This includes the suggestion that the international Rule of Law should be something more than a mere obligation to comply with promises. ${ }^{27}$ (The contrary position is that the international Rule of Law could simply reflect pacta sunt servanda. ${ }^{28}$ ) In this connection, states could be seen as: not being akin to individuals in the domestic sphere - as individuals are entitled to do anything that is not prohibited; ${ }^{29}$ being constrained in their exercise of unlimited power - through state's subjection to rules $;{ }^{30}$ being able, only in some

\footnotetext{
${ }^{26}$ By outlining only these features, I aim to provide enough detail to frame the common methodological approaches - which are expanded upon in the following sections - in a way that allows me to illustrate the existing issues. In this respect, and as my argument does not require me to do so, I do not claim to identify allor all nuances of - the issues within the debate.

${ }^{27}$ Hurd, 'The International Rule of Law and the Domestic Analogy' (n 4).

${ }^{28}$ See, for example, Rosa Brooks, 'Drones and the International Rule of Law' (2014) 28 Ethics International Affairs Journal 83.

${ }^{29}$ Waldron, 'Are Sovereigns Entitled to the Benefit of the International Rule of Law?' (n 19); Jeremy Waldron, 'The Rule of International Law' (2006) 30 Harvard Journal of Law \& Public Policy 15.

${ }^{30}$ Geert De Baere, Anna-Luise Chané and Jan Wouters, 'Assessing the Contribution of the International Judiciary to the Rule of Law: Elements of a Roadmap' (2015) Working Paper $157 \quad 18$ $<$ https://ghum.kuleuven.be/ggs/wp157-debaere-chane-wouters.pdf> accessed 29 November 2016.
} 
respects, to act with universal freedom — as a reflection of Hobbes's state of nature man writ large; ${ }^{31}$ or being subjected to a legal order that differs from the one governing people in a domestic sphere. ${ }^{32}$

The difference that underlies many of these accounts could be said-in part- to be exemplified by the difference in relative power structures often applied to the domestic and international spheres: domestic ideas relate to a vertical structure; and international ideas relate to a horizontal structure. Whilst this is a broad abstract generalisation and undoubtedly an oversimplified view of contemporary international law, it serves to illustrate and characterise one of the fundamental differences between domestic and international ideas in the debate. Whilst the nuances of international law are legion and the boundaries with and differences to domestic law could be seen to be increasingly blurred, such generalisation is not wholly inaccurate in terms of their relevance to the international Rule of Law debate. ${ }^{33}$

The second aspect of the international Rule of Law debate relates to the nature or existence of the international Rule of Law. Within this aspect, there are two broad positions. The first one is the frequently stated idea that the international Rule of Law is a concept that is, in varying senses, emerging. This relates either to the concept itself, ${ }^{34}$ to the concept in tandem with some related idea, ${ }^{35}$ or to the understanding that the international Rule of Law is something of a work in progress ${ }^{36}$ that

\footnotetext{
${ }^{31}$ Here, I am extrapolating from the general argument by Malcolm: Noel Malcolm, Aspects of Hobbes (New Ed edition, Oxford University Press, USA 2004) ch Ch. 14.

${ }^{32}$ It is in this sense that Hurd suggests ' $[\mathrm{t}]$ he role of international law in the relations among sovereign states is not analogous to the role of law among people in a domestic society.' Hurd, 'The International Rule of Law' (n 4) 40 .

${ }^{33}$ My conclusions mirror, to some degree, those provided by Richard Collins. See Richard Collins, 'The Rule of Law and the Quest for Constitutional Substitutes in International Law' (2014) 83 Nordic Journal of International Law 87.

${ }^{34}$ Gianluigi Palombella and Neil Walker (eds), 'The Rule of Law in International Law Today', Relocating the Rule of Law (Hart 2009) 220; Bernhard Zangl, 'Is There an Emerging International Rule of Law?' (2005) 13(1) European Review 73; Goodin (n 3).

${ }^{35}$ In relation to the evolution of the international Rule of Law with human rights see, for example, Tom Bingham, The Rule of Law (Allen Lane 2010) ch Ch. 10.

${ }^{36}$ Tamanaha (n 20) 127.
} 
may have its origins in the $16^{\text {th }}$ and $17^{\text {th }}$ centuries. ${ }^{37}$ What stands out from these accounts is the suggestion that the existence of the international Rule of Law, or at least its function, was greatly enhanced in the post-war period. In this respect, the increased prevalence of international institutions reflects the increased interest in the precise terms of the Rule of Law, which is, in turn, evident from the relative burst of 'canonical' Rule of Law authorship in the same period. ${ }^{38}$ The second positionwhich I will argue, in Section 3, adds a substantial complication to the discussion - is the idea that the concept of the Rule of Law itself is a fundamentally Western, more specifically an AngloAmerican, conception or that it is propagated largely by Western trained lawyers. ${ }^{39}$

Considering both general aspects - relating to the role states play within the international Rule of Law and the nature of such concept - two things become clear. First, even in the most basic sense, the identification of the international Rule of Law through recourse to domestic ideas cannotwhere commonly known conceptions of the Rule of Law directly reflect neither of the two mentioned aspects - be a simple proposition. The canonical domestic conceptions of the Rule of Law seem to be pre-primed with a socio-legal / geopolitical bias. As I will illustrate in greater detail later, these conceptions are the ones most frequently associated with the international Rule of Law.

The second point that becomes clear is that the international Rule of Law is different to the Rule of Law. Whilst some accounts suggest the international Rule of Law is the Rule of Law writ

\footnotetext{
${ }^{37}$ In several respects, this notion of a change or an evolution mirrors - broadly - the idea of change across Rule of Law concepts. Bishop (n 2) 555-560; Spencer Zifcak, Globalisation and the Rule of Law (Routledge 2004) $10-12$.

${ }^{38}$ I will return to this point later. See, for example, Hayek, The Road to Serfdom (n 17) (First edition published in 1944); Fuller (n 14); Raz (n 21) 210 (First published in the Law Quarterly Review 1977). A not dissimilar rash of Rule of Law-interest also followed the initial late $19^{\text {th }}$ century popularisation of the expression by Dicey. Albert Venn Dicey, Introduction to the Study of the Law of the Constitution (3rd edn, Macmillan and co, limited 1889) ch Ch. IV The Rule of Law.

${ }^{39}$ Chesterman (n 19) 340; Tamanaha (n 20) 134; Robert McCorquodale, 'Defining the International Rule of Law: Defying Gravity?' (2016) 65 International and Comparative Law Quarterly 277, 294; André Nollkaemper, Randy Peerenboom and Michael Zürn, Rule of Law Dynamics In an Era of International and Transnational Governance (Cambridge University Press 2012) 5-7; Bishop (n 2) 565; Gianluigi Palombella, 'The Rule of Law, Democracy, and International Law. Learning from the US Experience' (2007) 20 Ratio Juris 456, 479.
} 
large, ${ }^{40}$ the widely stated position is that there must be at least some modification to the domestic concept before it can be applied or be of relevance to the international sphere ${ }^{41}$ as the two concepts have different forms and objectives. ${ }^{42}$ Despite this general consensus, various commonly adopted approaches do derive the international Rule of Law from the Rule of Law: they use, borrow or extend ideas (either explicitly or implicitly) from domestic conceptions, employing them as a foundation for the international concept. ${ }^{43}$ In arguing against this practice, I build on the general consensus to argue that the Rule of Law conceptions cannot effectively provide either a useful or a relevant source from which to derive the international concept. I further illustrate two ways in which international Rule of Law formulations can avoid the criticisms that I make in this work.

\subsection{Is there Another Way?}

At this stage, I pre-empt many of the details of my own criticisms and provide two methodologies that provide a solution to the issues that I raise. These methodologies exemplify an alternative way to communicate an international Rule of Law idea. Whilst I do not claim that they are the only ways to avoid the criticisms that I raise, their existence demonstrates that it is possible to formulate an international Rule of Law conception without deriving it (implicitly or explicitly) from domestic ideas. In short, the existence of such methodologies, although not widely adopted, illustrates that derivation is, itself, unnecessary.

\footnotetext{
${ }^{40}$ Bingham (n 35) 111. Bingham suggests Chesterman's position fortifies this position and Bingham also cites Bishop in support. Chesterman (n 19); Bishop (n 2). However, I disagree with Bingham's characterisation of these accounts.

${ }^{41}$ Chesterman (n 19) 358; Waldron, 'Are Sovereigns Entitled to the Benefit of the International Rule of Law?' (n 19) 317; McCorquodale (n 39) 290-292; James Crawford, 'International Law and the Rule of Law' (2003) 24 Adelaide Law Review 3, 5-6; Stéphane Beaulac, 'An Inquiry into the International Rule of Law' (2007) 14 (2007) European University Institute Working Papers, MWP 1, 8-9.

${ }^{42}$ A variety of emphases in these respects can be found across Chesterman (n 19) 340; Palombella (n 39) 479; Hurd, 'The International Rule of Law and the Domestic Analogy' (n 4) 372; Hurd, 'The International Rule of Law' (n 4); Waldron, 'Are Sovereigns Entitled to the Benefit of the International Rule of Law?' (n 19); Palombella and Walker (n 34); Gianluigi Palombella, 'The Rule of Law at Home and Abroad' (2016) 8 Hague Journal on the Rule of Law 1. For a further purposive account of the Rule of Law, see Paul Burgess, 'The Rule of Law: Beyond Contestedness' (2017) 8 Jurisprudence 480.

${ }^{43}$ Whilst this is a basic statement about the nature of derivation, it will suffice for the moment. I will provide more detail in Section 4, when addressing the specific context of the methodologies employed.
} 


\subsubsection{Another way: non-reliance on earlier conceptions.}

In his 1961 paper, William H. Bishop provides a simple description of the international Rule of Law. He does so without reliance on others' Rule of Law-specific desiderata or theories. ${ }^{44}$ This is not to say he shuns previous ideas completely; he acknowledges the (1960s) international law system grew from $16^{\text {th }}$ and $17^{\text {th }}$ century ideas. In this way he innovates without shackling himself to or cloaking his conception in an earlier idea. ${ }^{45}$ Many of what are now considered canonical conceptions of the Rule of Law also do not refer to or seek to rely directly on earlier conceptions of the Rule of Law. ${ }^{46}$ When Bishop was writing, the voguishness associated with invoking the concept of the Rule of Law had not yet taken hold and many of the popular and generally considered canonical Rule of Law ideas had yet to emerge or receive popular acclaim. ${ }^{47}$ For example, Hayek's Road to Serfdom was first published in 1944, and Fuller's The Morality of Law was published two decades later in $1964 .{ }^{48}$ Yet, it seems, Rule of Law momentum was building. Dicey's account—originally published in 1885had been in existence for over half a century and had been published as a $10^{\text {th }}$ edition in 1959 , before being reprinted in each of the following three years. ${ }^{49}$ This period has been described as including a revival of the ideas of the Rule of Law, and it was during that time, and in the years immediately preceding the publication of Bishop's paper, that Dicey's Rule of Law idea-together with several associated ideas-were considered as being important to the general conception of Rule of Law ideas. $^{50}$

\footnotetext{
${ }^{44}$ Bishop (n 2). Bishop's account is stipulative. For the present analysis, the focus is on the way he states his account rather than what it is.

${ }^{45}$ For an explanation of how innovation can occur in this way, and for an account of the importance of origins in relation to the Rule of Law, see Paul Burgess, 'Neglecting the History of the Rule of Law: (Unintended) Conceptual Eugenics' (2017) 9 Hague Journal on the Rule of Law 195.

${ }^{46}$ See, for example, Locke (n 6); Fuller (n 14).

${ }^{47}$ Krygier, 'Pasts, Presents, and Futures' (n 13$) 1$.

${ }^{48}$ Hayek, The Road to Serfdom (n 17); Fuller (n 14).

${ }^{49}$ Dicey (n 6) (Preface to the 10th edition and Prelims).

${ }^{50}$ Arndt (n 12).
} 
What is acknowledged by Bishop is that the international sphere underwent a fundamental change from earlier centuries before undergoing a further change in the post-war period. ${ }^{51}$ What is also apparent (to us), is that this change has continued to see the expansion—and, some would say, the fragmentation - of international institutions to a point that may render the very idea of the international order largely unrecognisable to Bishop (let alone to his $16^{\text {th }}$ and $17^{\text {th }}$ century conceptual predecessors.) In terms of authors who are frequently associated with the Rule of Law-like Aristotle, and Locke - and the concept's oft cited ancient origins, ${ }^{52}$ a similar sentiment may be apposite: the international legal order as it operates today — and the internationalisation of their and other Rule of Law usual suspects' ideas - may have been substantially beyond their comprehension. Attributing this specific knowledge or any awareness of this application to them could be seen as anachronistic, since it relates to an understanding that they could not possibly hope to have had in a field to which they could not hope to have contributed. ${ }^{53}$ In this sense, Bishop's avoidance of reliance on, or derivation from, older conceptions seems prudent; it avoids anachronism and identifies the international concept as an independent idea. Bishop's approach to providing an account of the international Rule of Law illustrates one form of a solution to the issues that I outline in this paper.

\subsubsection{Another way: a problem / solution approach.}

Ian Hurd suggests the international and domestic concepts of the Rule of Law were created to provide solutions to fundamentally different political problems and are different in their logic,

\footnotetext{
${ }^{51}$ Bishop (n 2).

${ }^{52}$ Martin Krygier, 'Rule of Law (and Rechtsstaat)' in James R Silkenat, James E Hickey and Peter D Barenboim (eds), The Legal Doctrines of the Rule of Law and the Legal State (Rechtsstaat), vol 38 (Springer International Publishing 2014) 46; Jeremy Waldron, 'Legislation and the Rule of Law' (2007) 1 Legisprudence 91, 101; Tamanaha (n 20) 7. See also Paul Burgess, 'Should Entick v. Carrington Be on Our Rule of Law Radar?' (2016) 16 Jus Politicum 281.

${ }^{53}$ See, for example, Quentin Skinner, Visions of Politics (Cambridge University Press 2002) 59-60. Skinner's widely adopted approach - that can be seen as paradigmatic of one way of contextualising a text - I requires a close assessment of exactly what an author was doing in her or his text. Conflating the significance of a work with the account of what the author was actually doing, could also be conceived of in terms of the Skinnerian 'sin' of prolepsis. ibid 73 .
} 
history, and content. ${ }^{54}$ In providing his account, Hurd illustrates clearly that there is a difference between the international and domestic Rule of Law spheres; this is a point that I will echo and return to shortly. Whilst his idea could—generally—be part of the overarching acknowledged difference in the concepts' origins and objectives, his conception of this factor in problem / solution terms is the point I wish to highlight. This line of thinking is not, however, completely unprecedented as the Rule of Law has previously been described as 'a solution concept' or as a response to a particular problem. $^{55}$

This problem / solution idea will be explored and expanded upon in the next part. At this stage, and in relation to the issue of how an alternative way in which the international Rule of Law can be conceived, it will suffice to point out that the problem / solution approach requires international ideas to be conceived only as being properly related to the domestic ones if the problem and solutions are the same. In this sense, the approach provides some guidance, albeit in negative terms, as to how the international Rule of Law can be located. In other words, Hurd's suggestion is geared to providing, and specifically considering, much needed context to both earlier and current ideas of the Rule of Law. Accordingly, Hurd, like Bishop, illustrates one other way to formulate ideas of the international Rule of Law that avoids the shortcomings of the derivative approach.

Notwithstanding the approaches adopted in the past, in a contemporary context and given the recent popularity of various conceptions of the Rule of Law, it may seem peculiar-if not unthinkable and, potentially, sloppy academic practice - to produce a Rule of Law account of anything without mentioning earlier canonical ideas. However, it seems that there is a difference-which is infrequently illustrated in the debate — between the attribution of the origins of an idea to an earlier thinker and the application of that idea. This difference is more than semantic. Its recognition is vital

\footnotetext{
${ }^{54}$ Hurd, 'The International Rule of Law' (n 4) 41. For Hurd's most recent expansion of this point, see Ian Hurd, How to Do Things with International Law (Princeton University Press 2017).

${ }^{55}$ Waldron, 'Is the Rule of Law an Essentially Contested Concept (in Florida)?' (n 8) 158; Douglass C North and Barry R Weingast, 'Constitutions and Commitment: The Evolution of Institutions Governing Public Choice in Seventeenth-Century England' (1989) 49 The Journal of Economic History 803, 816; Noel B Reynolds, 'Grounding the Rule of Law' (1989) 2 Ratio Juris 1, 5. See also, Martin Krygier, 'The Rule of Law After the Short Twentieth Century: Launching a Global Career' in Richard Nobles and David Schiff (eds), Law, Society and Community: Socio-Legal Essays in Honour of Roger Cotterrell (Ashgate 2014).
} 
to avoid the criticisms that I make. In Section 4-broadly in line with Bishop-I will discuss the problems that follow from attempts to modify Rule of Law conceptions. First, however, in Section 3-broadly in line with Hurd - I will suggest that ideas should be read in context and in terms that relate to a problem / solution understanding. The result, I argue, is that Rule of Law conceptions cannot be effectively internationalised through the derivative process, which both popularly and currently takes place.

\section{Deriving the International Rule of Law: An Unnecessary Exercise (the Argument from Context)}

In deriving an international Rule of Law idea one premise exists: Rule of Law conceptions can provide a useful or relevant source from which we can derive the international concept. ${ }^{56}$ I challenge this premise. I argue that Rule of Law conceptions cannot provide a useful or relevant source from which we can derive the international concept and suggest it is not possible to-effectivelyinternationalise domestic conceptions of the Rule of Law. The rationale for my challenge is rooted in the fundamentally different contexts of the two spheres. If my argument from context is accepted, and as my argument challenges a premise undergirding the international Rule of Law debate regarding the way in which the international Rule of Law is derived, both the need for derivation and the discussion concerning the way in which such a derivation should occur-which I explore in more depth in Section 4-become unnecessary. It is in these senses that I make my titular suggestion that deriving the international Rule of Law is an unnecessary exercise.

My argument from context comprises two sub-arguments. The first one is an abstract argument that —in virtue of the lack of commonality in conceptions' contexts, and as a result of a common parochial perspective - the Rule of Law cannot be effectively internationalised. The second sub-argument consists of applying the abstract argument to two thinkers' conceptions that are frequently deployed in the international debate — and are used as a basis for derivation: those of Dicey

\footnotetext{
56 This premise undergirds the derivative processes associated with the approach that I criticise in Section 4.
} 
and Hayek. In doing so, and with an eye on the other ways to identify the international Rule of Law addressed in the previous section, I illustrate that the common practice of deriving the international Rule of Law is unnecessary given that there are alternative ways to locate the idea that do not succumb to the criticisms that I make.

\subsection{The Abstract Argument: Why the Rule of Law Cannot (Effectively) be}

\section{Internationalised}

Rule of Law conceptions cannot be internationalised in any useful sense because any attempt to do so results in potentially nonsensical—or at least substantially unclear-results. This is the case as the context in which domestic ideas were conceived differs fundamentally from the context in which the international Rule of Law exists. Here, I provide a brief abstract argument in terms that advocate a contextualist consideration of the Rule of Law. ${ }^{57}$ I use this abstract argument to introduce the bones of the ideas to which I substantially add flesh in the following sub-section. My abstract argument has two prongs; both relate to the fundamental importance of considering context in assessing Rule of Law ideas and, furthermore, both — in many ways - agree with the approaches adopted by Bishop and, especially, Hurd. ${ }^{58}$ The first prong outlines the necessity of context to ensure that we are comparing 'apples with apples' when we think about the various canonical Rule of Law conceptions. The second (related) prong suggests the fundamental difference that exists between the domestic and international Rule of Law contexts restricts the application of those ideas to its relevant sphere.

\subsubsection{First prong: the conceptions' context.}

To show that Rule of Law conceptions cannot be internationalised given the different contexts in which the ideas operate, I illustrate — by use of a simple example — the dangers of considering conceptions when they are devoid of context. In doing so in relation to the Rule of Law, I rely on

\footnotetext{
${ }^{57}$ For the classic statement of contextualist ideas, see Quentin Skinner, 'Meaning and Understanding in the History of Ideas' (1969) 8 History and Theory 3.

${ }^{58}$ Hurd, 'The International Rule of Law' (n 4); Bishop (n 2).
} 
one-hopefully uncontroversial—premise: that conceptions of the Rule of Law are capable of representing solutions to problems that were perceived by the conceptions' authors. Although the crux of my suggestion, as a problem / solution approach, is in similar terms to that which is advocated by Hurd, ${ }^{59}$ I will borrow R.G. Collingwood's helpful formulation. In applying Collingwood's idea to Rule of Law-relevant terms, it is possible to say we can only properly understand a (Rule of Law) solution if we understand the correlative (Rule of Law) problem. ${ }^{60}$ Similarly: we cannot assume there is a contest between theorists because two answers are different (as they could still mean the same thing); and we cannot assume there is agreement between theorists because two answers are the same (as they could still mean something different.) In other words: there exists a genuine disagreement only if there are inconsistent views about the same subject matter; or, assessing the other side of the relationship, there exists a genuine agreement only if there are consistent views about the same subject matter. To exemplify, consider two questions:

\section{Q.1 What time will we eat?}

Q.2 How many people have walked on the moon?

If the answers provided to Q.1 and Q.2 are, respectively, 'noon' and '12', the answers' meaning is clearly different. However, it is equally obvious that the answer to both questions could be ' 12 '. In this sense, despite answers being in the same terms, it is apparent they mean something very different. This difference is clear by virtue of the questions' context.

What if the same question is asked to two individuals? If Q.1 only is posed, both individuals' answers could be ' 12 '. Another pair of answers could be ' 12 ' and 'in an hour'. In considering the first pair — where both answer ' 12 ' - the issue here is that, despite the question being the same, the same answers may, nevertheless, mean something different — as, here, one answer may refer to noon, and the other to midnight. To further complicate matters, in thinking about the second pair of

\footnotetext{
${ }^{59}$ Hurd, 'The International Rule of Law' (n 4).

${ }^{60}$ Robin George Collingwood, An Autobiography (Oxford University Press 1939) ch Ch. V.
} 
answers - ' 12 ' and 'in an hour' - both could mean the same thing (if we consider the question here was posed at $11 \mathrm{am}$ and both people intended to refer to noon) despite being in different terms.

Appreciating the meaning of the answer is crucial in assessing whether two answers actually agree (or not). Meaning can, I suggest, only be comprehended by understanding both the question and the context of the question being raised, as well as the answer and the context of the answer being given. To bring this back to the issue at hand, the meaning of a Rule of Law conception (as a solution) can only be effectively understood - and effectively compared or contrasted with other Rule of Law conceptions - if the meaning of the conception (as a solution) is understood in context of the solution's authoring as a response to a particular problem. If we consider —as per my premise - the authoring of the solution as responding to problems that were perceived by the conceptions' authors, identifying the problem itself is also critical. The consideration of the context of the conceptions' authors at the time of writing is not only fundamental but also is, I suggest, fundamentally underappreciated in discussions of the Rule of Law and the international Rule of Law. ${ }^{61}$

The domestic or international Rule of Law conceptions (as solutions) — even if they are in the same or very similar terms - may mean something different as the context of the international and domestic ideas (as problems) differs. It is possible to expand this further. Attempting to derive a conception of the international Rule of Law from domestic conceptions, where the fundamental context — of the problems faced — differs, requires more than the importation of a Rule of Law conception (based solely on its classification as a Rule of Law idea or its similarity to any preconceived idea of what the Rule of Law is or should be.) It requires the context to be the same; the problems, in both spheres, must be the same. This situation - as will be expanded upon following the explanation of the second prong - does not obtain across the international and domestic spheres. Without this, the result is that, not only are we comparing apples with oranges, but we are doing so in the hope of making lemonade.

\footnotetext{
${ }^{61}$ For an argument outlining the importance of considering the origins and precise nature of conceptions of the Rule of Law, and the relative dearth of consideration in these terms, see, Burgess, 'Neglecting the History of the Rule of Law: (Unintended) Conceptual Eugenics' (n 45).
} 


\subsubsection{Second prong: non-international conceptions.}

The second prong of my abstract argument is closely related to the first and can be briefly stated: the conception of Rule of Law ideas in a thoroughly and obviously domestic context prevents the effective application of those ideas to the international sphere. Putting this another-more problem / solution relevant-way, my argument is that if the context of the domestic and international conceptions relates to fundamentally different problems, then the domestic solutions cannot be expected to answer an international problem effectively. Although related, the first and second prongs can be conceived independently.

In the Rule of Law debate, the majority of the canonical conceptions are conceived within the Anglo-American legal tradition. Even if, notwithstanding the Anglo-American-ness of the debate, the ideas are considered more broadly as Western ideas, they still cannot be conceived of as being truly representative of an international context. The problems concerning particular domestic ideas are fundamentally domestically based. International solutions that are derived from and premised on solutions formulated in a particularly domestic (Anglo-American) view of the world can, without arbitrarily importing additional criteria, reflect only that Anglo-American view of the world.

It is surely the case that an Anglo-American view of the law or legal institutions more generally_whilst pervading in many areas of the law, including international law-cannot represent an international viewpoint (should such a thing even exist). In the absence of any indication that the Anglo-American view is representative of an international perspective, and in circumstances where the context of the idea is required to be the same, then attempting to use those (domestic) conceptions renders any attempt to derive the international Rule of Law from those ideas unavoidably parochial. This is the case because the problems being addressed were local / domestic problems. (This is illustrated in the next section.) In other words, and in relating this prong to the first, as the parochial context restricts the application of domestic ideas to that sphere, there is no way to effectively derive a - truly international - international Rule of Law solution from Rule of Law conceptions. In 
summary, the problems to which the Rule of Law accounts relate are domestic problems. As will be seen, these problems do not translate to, and cannot be seen in, the international sphere.

\subsection{The Abstract Argument Illustrated: Why (Dicey and Hayek's) Rules of Law Cannot}

\section{Internationalise}

In order to illustrate the difference in the problems and solutions across the international and domestic spheres, I apply the two prongs of the abstract argument to two of the most frequently invoked Rule of Law theorists in the international Rule of Law debate: Dicey and Hayek. By concentrating on Dicey and Hayek, I am not suggesting either one — or a combination — constitutes the entirety of the contribution to the international debate. However, it is clear they occupy a privileged position as common sources from which the international Rule of Law conceptions are derived. Accordingly, not only is my focus on these particular canonical Rule of Law thinkers warranted, but it also reflects what the international Rule of Law is (commonly taken to be). For this reason, those authors represent ideal candidates to illustrate the application of my abstract argument.

Dicey and Hayek's initial Rule of Law theories were published in 1885 and 1944 respectively. ${ }^{62}$ It does not take formal training as a historian to appreciate that the world (and international law) has changed dramatically in the intervening period: Hayek's world was not Dicey's. Furthermore, the modern world is not the world of either Dicey or Hayek. Whilst some theories may be timeless in their application, their Rule of Law conceptions are not of that kind. The specific context in which they were formulated both matters and is not universal or international in character. By considering both theorists' ideas in terms of the problem / solution approach outlined above, and by regarding the nature of the problem that each theory was focussed on solving, it becomes apparent why context matters to the international Rule of Law debate; and it becomes clear that the problems that motivated Dicey and Hayek are very different to the problems that exist in the international sphere. In turn, this supports my broader conclusion in this section: conceptions of the

\footnotetext{
${ }^{62}$ Dicey (n 38); Hayek, The Road to Serfdom (n 17) x.
} 
Rule of Law cannot effectively internationalise. To this end, it is useful to provide a basic thumbnail sketch of each theory as well as each theorist's position in time and the world.

\subsubsection{Dicey's Rule of Law.}

Dicey's Rule of Law account is not only commonly deployed, but it is also identifiable as the backbone of many international Rule of Law formulations. This may result from the relative simplicity of his formulation that calls for: the absence of arbitrary power on the part of the government; equal application of the law (meaning no individual is above the law and all are subject to the law); and, judicial decisions are to be privileged (as general principles of the constitution result from judicial decisions). ${ }^{63}$

In the debate regarding the content of the international Rule of Law, a broadly Diceyean formulation has frequently been: applied in recognisably similar but slightly reduced or supplemented terms as an idea representing the core of the Rule of Law; ${ }^{64}$ specifically augmented with human rights; $;{ }^{65}$ or used as the basis, in conjunction with other ideas, for identifying essential elements of an international Rule of Law. ${ }^{66}$ (This aspect of indirect derivation will be explored and expanded upon, below.) It is noteworthy that, whilst Hayek's account — in particular, his requirements for certainty and predictability — has also been used as a base for the idea of the international Rule of Law, ${ }^{67}$ it is frequently mentioned as an adjunct to Dicey's conception ${ }^{68}$ or as a supplement to deriving Rule of Law elements in order to explore how this has been used in international fora. ${ }^{69}$ Dicey and Hayek's theories, accordingly, form two common — and frequently co-applied—foundational bases for

\footnotetext{
${ }^{63}$ Dicey (n 38) 175, 180 and 183.

${ }^{64}$ Hurd, 'The International Rule of Law and the Domestic Analogy' (n 4) 369; Chesterman (n 19) 342; Crawford (n 41).

${ }^{65}$ McCorquodale (n 39).

${ }^{66}$ Palombella and Walker (n 34).

${ }^{67}$ Zifcak (n 37) 36.

${ }^{68}$ Beaulac (n 41) 202; Hurd, 'The International Rule of Law and the Domestic Analogy' (n 4) 369.

${ }^{69}$ Chesterman (n 19) 342-3; Waldron, 'Are Sovereigns Entitled to the Benefit of the International Rule of Law?' (n 19) 317.
} 
international Rule of Law ideas. Together, their usage illustrates the way in which derivation frequently occurs.

It has been stated that Dicey was as satisfied with his Rule of Law account in 1908 as he was in 1884 , despite being aware of societal and political developments across that time. ${ }^{70}$ This is, perhaps, as he sees the concept as remaining relatively constant. He describes the Rule of Law as one of two features - with the other being the supremacy of the central government — that have, at all times since the Norman conquest, been characteristic of England's political institutions. ${ }^{71}$ The decline in the Rule of Law and the accompanying rise in the welfare state provide motivation for Dicey's ideas and they underscore the problem that he seeks to solve.

In framing his Rule of Law conception, in particular his ideas associated with the absence of arbitrary power and the equal application of the law, Dicey contrasts this with governments based on arbitrary or discretionary powers (frequently using France as a foil.) ${ }^{72}$ In fact, whilst noting that the Rule of Law could be seen as a trait common to every civilised or orderly state, his consideration of Europe at that time suggests the-Diceyean — Rule of Law is particular to England (and countries that have inherited English traditions. $)^{73}$ In short, Dicey sees the rise of the administrative state as the (Rule of Law) problem. His (Rule of Law) solution is parochial in the extreme in its Anglo-centric, and somewhat Franco-phobic, outlook. Thus, the Diceyean context reflects both prongs of the abstract argument (both the necessity of context to ensure we are comparing 'apples with apples', and that the differences between the domestic and international spheres restricts the application of ideas to each particular sphere.)

\subsubsection{Hayek's Rule of Law.}

\footnotetext{
${ }^{70}$ FH Lawson, 'Dicey Revisited. I' (1959) 7 Political Studies 109.

${ }^{71}$ Dicey (n 38) 171.

72 ibid Ch. 4.

73 ibid 176.
} 
Hayek's Rule of Law conception is connected yet very different to Dicey's. The appeal of Hayek's conception may not have been immediate. Yet, it was, at least by 1977, considered by Joseph Raz as providing one of the clearest and most powerful formulations of the Rule of Law. ${ }^{74}$ Hayek sees himself as doing something fundamentally different to Dicey. In a footnote to his oft cited Rule of Law definition, Hayek explains a clear difference in both scope and origin between his idea of the Rule of Law and that of Dicey:

\begin{abstract}
Largely as a result of Dicey's work the term has, however, in England acquired a narrower technical meaning that does not concern us here. The wider and older meaning of the concept of the rule or reign of law, which in England has become an established tradition which was more taken for granted than discussed, has been most fully elaborated, just because it raised what were new problems there, in the early nineteenth-century discussion in Germany about the nature of the Rechtsstaat. ${ }^{75}$
\end{abstract}

Hayek's work can be seen as an attack on socialism. Whilst predictability is one of the key themes that run throughout his various Rule of Law works, ${ }^{76}$ state coercion is, for him, a fundamental problem that can be tempered only by the actions of a limited government being predictable. ${ }^{77}$ As a proponent of classical liberalism, his fear of socialism was not merely confined to the rise of the Nazis in Germany. Nationalisation and state control of resources in the United Kingdom during World War II give rise to a fear in Hayek that those measures may continue after the war. ${ }^{78}$ For Hayek, this problem could be solved by constraining the government's actions and by allowing an individual to plan around state action and, therefore, avoid coercion.

\title{
3.2.3. Dicey and Hayek: problems and solutions.
}

A detailed comparison between Dicey and Hayek's theories is unnecessary as this does not concern the international Rule of Law debate. However, it is useful to sketch some basic points that illustrate relative differences to the international sphere. There are undoubted similarities between Hayek and

\footnotetext{
${ }^{74} \operatorname{Raz}(\mathrm{n} 21) 210$.

${ }^{75}$ Hayek, The Road to Serfdom (n 17) 112.

${ }^{76}$ Hayek, The Road to Serfdom (n 17); Friedrich A von Hayek, The Constitution of Liberty (University of Chicago Press 1960); Friedrich A von Hayek, Law, Legislation and Liberty: The Political Order of a Free People, vol 3 (1973).

${ }^{77}$ Hayek, The Road to Serfdom (n 17) 112.

${ }^{78}$ ibid 11 .
} 
Dicey; but there are also important differences. Both thinkers' projects reflect their fears of the decline of the Rule of Law in the United Kingdom. But their solutions are - and, as I will argue, must be viewed - in different terms given the different problems that they perceive. Both sets of problems differ, as will be seen, to the international sphere.

Dicey and Hayek are addressing different problems and are proposing different solutions. Given Hayek's express comments referring to Dicey's ideas quoted above, they cannot simply be assumed to be talking about the same thing (should there even be a 'thing' that could be attributed to the Rule of Law as a single ideal or concept.) Despite this, both theorists are frequently lumped together as talking about the Rule of Law and their ideas are - as has been outlined above- often mixed and matched in creating the international Rule of Law as if they are both pieces of the same jigsaw. Even if that was the case in relation to conceptions of the Rule of Law (and I do not think that it is) it seems even less likely to be true for conceptions of the international Rule of Law as neither author appears to have had — or, perhaps, was even capable of having — that particular application in his contemplation. In determining if this is the case, it is, therefore, necessary to analyse the context of their ideas when considering whether it is apposite to apply and augment their theories as frequently occurs in the international debate.

A compelling case for reading Dicey in context was made by F.H. Lawson in $1959 .{ }^{79}$ In the same year, Lawson's comment was mentioned in the preface to the $10^{\text {th }}$ edition of Dicey's text by E.C.S. Wade, who states that, notwithstanding the growth in interest in the Rule of Law in the previous two decades, there have seldom been any additions suggested to Dicey's Rule of Law principles. ${ }^{80}$ Dicey and Hayek's differing problems do, at least in part, have a shared geographical context: they were each responding to crises that they observed in the United Kingdom in their (respective) times. Yet, the vast differences between late- $19^{\text {th }}$ century and mid-20 $0^{\text {th }}$ century England seem capable of rendering that geographical similarity inconsequential. Accordingly, whilst it may be intuitively correct that solutions sharing a similar context —in relation to the nature of the relevant

\footnotetext{
${ }^{79}$ Lawson (n 70); FH Lawson, 'Dicey Revisited. II' (1959) 7 Political Studies 207.

${ }^{80}$ Dicey (n 6) ix-x.
} 
problem - should have the best prospects of being successfully applied together, there is no common problem for Dicey and Hayek.

In circumstances where the fundamental problem that undergirds a theory no longer obtains, does the theory remain relevant? Is it appropriate to make modifications? Can any modifications 'save' a theory and allow its application outside of the context in which it was formulated? In the context of the international Rule of Law, and at the risk of sounding overly negative, I argue in the remainder of this section that the answer to each of these three questions should be 'no'. Now that we have an understanding — however basic — of both Dicey and Hayek, we can apply their ideas to the two prongs of my abstract argument. By doing so, I provide two reasons for my negative responses to the questions above.

\subsubsection{Reason One: the conceptions' context.}

Both thinkers' solutions are ascribed—-by at least Hayek's subsequent design—-the common title the Rule of Law. Notwithstanding this nomenclatorial similarity, the theorists had very different projects and their Rule of Law solutions - when considered alone and in the context of their problems - differ substantially. To continue the jigsaw metaphor, even if the pieces could be made to physically fit together, any image ultimately resulting from the mixing of the pieces would likely be both confusing and, after all, not representative of either author's argument.

By suggesting Dicey and Hayek's contexts were profoundly different to the context in which the international Rule of Law is situated, I do not argue the early $21^{\text {st }}$ century is devoid of problems associated with the fear of totalitarian or arbitrary rule or the coercion of the populous through the imposition of unknowable sanctions. I simply propose the relevant context to be considered is not that within individual states. It is, instead, that associated with the context of international Rule of Law and, relatedly, the realm of international law more broadly. In this realm, the problems to which Dicey and Hayek respond do not obtain. 
In considering Dicey's fear of the rise of the administrative state and the potential for arbitrary rule, or Hayek's fears related to the actions of an unpredictable sovereign, the association of states or contemporary international institutions or organisations - even without taking the extra step of conceiving the different societal conditions to which each author's fears correspond — does not appear to be capable of reflecting or giving rise to similar fears. The international Rule of Law context is a collaborative system that is characterised and constituted by compacts between nations in which there is no all-powerful sovereign. ${ }^{81}$ In this sense-whilst it is accepted that there is a practical reality that any state participant cannot extricate itself from the international order, and that there can be overbearing pressure that operates on weak states to accede to the wishes or demands of stronger states - the fundamental fear of arbitrary rule that characterised Dicey's work largely falls away when the tempering of the vertical exercise of power gives way to horizontal constraints. Further, the essential role played by courts in Dicey's solution cannot be seen clearly in the international judicial system; the lack of a compulsory universal and automatic jurisdiction not only renders courts somewhat ineffective, but it also means that Dicey's requirement that everyone be subject to the law is also inapplicable. For these reasons, it becomes difficult to conceptualise the domestic and international systems as relating to the same problems (or solutions).

Even if the context of the-Diceyean-solutions may seem to fit with contemporary problems, the context of the-Diceyean-problems appears to be irreconcilable with their contemporary international Rule of Law counterparts. Putting this another way, it is clear that Dicey's account of the Rule of Law reflects a fear of, in large part, arbitrary rule. Where there is no sovereign, arbitrary rule in the form that Dicey feared cannot subsist. The problem / solution approach requires

\footnotetext{
${ }^{81}$ In providing this very basic definition I do not wish to be perceived as only adopting an archaic view of the role and nature of international law. (I am indebted to the anonymous reviewer for pressing me for ever more clarity on this issue.) By using this broad idea, I mean to encompass all aspects of contemporary relations between states and organisations on the international plane. I do not merely wish to include ideas of bilateral agreements, or even multilateral agreements. I mean to include all of the functions that encompass the broadest idea of compacting that extend to the role that states play in terms of governance. In this respect, the idea I suggest forms the context for the international Rule of Law reflects the broad compact that individuals enterand maintain - a social contract to avoid a state of nature. In this respect, I include in my idea of the international sphere all three levels of Weiler's strata: the transactional, the communal, and regulatory. Joseph HH Weiler, 'The Geology of International Law-Governance, Democracy and Legitimacy' (2004) 64 Zeitschrift für ausländisches öffentliches Recht und Völkerrecht 547.
} 
that we view solutions that are in the same terms as being different solutions if they stem from different problems. In this respect, the different problem contexts illustrate that adopting Dicey's (domestic) Rule of Law solution cannot be an effective way to solve the international problem.

But what of Hayek's context? The point can be illustrated by simply exploring one of the most pervasive aspects of his Rule of Law conception: predictability. If the fundamental problem associated with Hayek's work is the lack of predictability that he saw arising from, inter alia, the rise of socialism and the nationalisation of state assets, the outcome will be similar to that resulting from the Diceyean analysis: the-Hayekian-problem does not reflect the contemporary context of international law. When considering whether sovereigns are subject to the Rule of Law, Jeremy Waldron suggests states in the international order cannot be seen in terms synonymous with people in the domestic order, as states, unlike individuals, are routinely involved in making the laws that bind them; they are, in effect, both a source and an official of international law. Waldron's general point, whilst open to criticism, is immediately applicable. ${ }^{82}$ The operation of the law in the international sphere that relates and is relevant to the international Rule of Law, and the sanctions that flow from it, results in large part from individual states' participation in creating and agreeing to be bound by international law. In thinking this way, unpredictability of action as a problem cannot have the same force and impact in the international sphere as Hayek feared in the domestic one. This is because, in the domestic sphere, Hayek feared coercion of the state in terms that meant individuals were unable to plan to avoid being coerced. To put my point another way, where Hayek's problem related to the rise of socialism and the nationalisation of state assets, this sort of problem is not a realistic problem on the international plane; there is no single totalitarian entity capable of taking such actions.

\footnotetext{
${ }^{82}$ Waldron, 'Are Sovereigns Entitled to the Benefit of the International Rule of Law?' (n 19) 328-331. Waldron's position has been challenged. See, for example, the comments and responses to his article (and his own response) in 'Symposium: Are Sovereigns Entitled to the Benefit to the International Rule of Law?' (2011) 22 European Journal of International Law 313, 313-400. However, notwithstanding the criticisms raised, the utility of this specific point remains.
} 
Based on this brief assessment, and considering the problem / solution terms, applying Dicey and Hayek's theories to the contemporary international Rule of Law context becomes problematic given the relative differences between the authors' contexts and that in which the concept of the international Rule of Law operates. But is it appropriate or possible to make modifications to the theories in order that they can be 'saved' and applied beyond the original context? After all, application is seldom attempted without some form of augmentation or amendment. ${ }^{83}$ To answer this question, and to remain in step with the broad contextualist methodology I adopt, I turn (in a very basic sense) to some of the ideas associated with the Cambridge School of intellectual history and, most prominently, those of Quentin Skinner. ${ }^{84}$ In this regard, identifying exactly what a canonical author was doing in positing his or her conception or idea is crucial. Modifying a theory-as a solution - to fit a different problem would seem to do fundamental violence to the original idea. The result may still be $a$ solution to $a$ problem but that solution would not properly constitute a modification (of, in our example, either Dicey or Hayek's idea) as it fundamentally cannot represent what either thinker was doing in her or his work. The solution would be, hence, a new idea. Of course, it could be suggested that the 'modified' idea simply leans on or borrows from one or other of these thinkers' conceptions and seeks to extend the idea organically. In this sense, I suggest the necessary requirement for a connection between the problem and solution remains strong enough to render solutions-even those in the same terms - conceptually different if they result from different problems. This much is apparent from my general application of Collingwood's idea in the first substantive point of this section. ${ }^{85}$ For example, as the same answer to Q.1 and Q.2 above may mean something different, in considering Hayek's core idea of predictability, even if both international and domestic conceptions comprise predictability as a solution, those solutions should be viewed as being, despite their superficial similarity, fundamentally different as a result of their different origins.

\footnotetext{
${ }^{83}$ For further details, see Section 4. Deriving the International Rule of Law: An Impractical and Unhelpful Exercise (The Argument from Origins)

${ }^{84}$ See, for example, Skinner (n 53).

${ }^{85}$ See supra note 60 and associated text.
} 
The argued modification, then, of any solution would sever the relationship with the problem — and solution — in its originally stated form: modification of either thinkers' theory to fit new contextual parameters of the international arena holds neither side of the problem / solution equation as being constant. In this sense, maintaining that the resulting international Rule of Law solution is a modification seems to be, at best, a strained suggestion. It properly represents a new solution. This is the case, even if the solutions are in precisely the same terms, by virtue of the different problems. (This position is equally relevant to the inclusion of arbitrarily selected components of a conception outlined in Section 4.) Of course, the problem cannot be simply modified; it is either what it is or what it was conceived to be-through the author's perception of that problem - as evidenced in the initial author's conception. If the problem is the same, then there is no issue of compatibility; but this is not the case. As the problems are not the same, a solution to a different problem will not, as has already been stated, take us any further in attaining clarity; it does not take us any further in effectively using the earlier account to derive a later idea of the concept. For these reasons, and where other ways exist (like Bishop and Hurd, for example), it is unnecessary to resort to derivation from the domestic accounts.

As illustrated through exploring the use of Dicey and Hayek's ideas in the international Rule of Law debate, by relying on any earlier domestic Rule of Law conceptions — which have a different contextual origin - it is not possible to effectively internationalise ideas conceived as solutions to problems when the problems' and solutions' context fundamentally differs from that in which the international Rule of Law exists.

\subsubsection{Reason Two: adopting non-international conceptions.}

But what of the second reason why conceptions of the Rule of Law cannot internationalise? The fact that Dicey and Hayek are proposing conceptions that are fundamentally Western ideas results in a further reason why the domestic ideas cannot internationalise. As noted, there is a geographical similarity between Dicey and Hayek. But this similarity can pose a problem in relation to a 
purportedly international concept; citation and reliance on authors and ideas that represent only a small portion of the world could be seen as being — in the least—problematic.

The context in which Dicey was writing and in which he was proposing his ideas was the situation in England. Whilst Hayek's view was less parochial, it undoubtedly communicates what could be described as a fundamentally Anglo-American or Western view of the Rule of Law. Of course, as noted above, positions like these within the international Rule of Law debate are not unusual. Putting aside for one moment the broader ideas associated with a Western / non-western idea, it is possible to say that the international Rule of Law debate encompasses an even narrower perspective as a result of its more restrictive Anglo-American focus. Hayek recognised this relative specificity in the extracted footnote above in relation to the Rechtsstaat ${ }^{86}$ whilst continental 'equivalents' to the Rule of Law are sometimes noted, the nature of the differences are far from being unrecognised. ${ }^{87}$ Of course, the bias could relate to the fact that the international Rule of Law debate is being conducted in English, with the majority of the contributors being based in English speaking institutions. Yet, that does not account for the more general interest and focus on the Rule of Law within the international institutions; especially where various declarations from these institutions have stressed the importance of the concept in the international sphere. ${ }^{88}$

My intent here is not to suggest that this international approach itself is misguided-it, of course, stands to reason that the various international institutions would reflect a strongly Western perspective given their genesis in the views of the victorious Great Powers at the end of World War II. I simply hope to point to the — contextual—problem of seeking to apply and rely on strongly Anglo-centric ideas of the Rule of Law in an international context in support of a specifically 'international' concept. ${ }^{89}$ In a sense similar to the reason one outlined above, and in terms of a problem

\footnotetext{
${ }^{86}$ See supra note 75 and associated text.

${ }^{87}$ See, for example, Krygier, 'Rule of Law (and Rechtsstaat)' (n 52).

${ }^{88}$ Declaration of the High-Level Meeting of the General Assembly on the Rule of Law at the National and International Levels 2012; Venice Commission of the Council of Europe, 'The Rule of Law Checklist' (2016).

${ }^{89}$ In reflecting the general approach advocated in this chapter, it seems to me that the context in which the major institutions of the International Law and formative ideas that relate to the environment in which the international Rule of Law could be seen to operate should not constrain today's best practice of identifying a truly international conception of the international Rule of Law.
} 
/ solution framework, the relationship seems strained as the conceptions' geographic limitations are not capable of internationalisation without substantial modification that would either alter the fundamental nature of the conception or destroy any actual connection between the two (pursuant to the problem / solution approach.)

Even in circumstances where the precise meaning and content of the international Rule of Law is unknown — and putting aside for one moment the substantial debate that exists in relation to the meaning and appropriate content of domestic conceptions of the Rule of Law-it seems like a very long and non-cosmopolitan bow to draw to assume that the international idea would, or should, reflect — specifically — the same terms as a purely Anglo-American perspective espoused by theorists only from within that particular context. What is, instead, suggested is that, in circumstances where the core conceptions deployed as a basis for the debate reflect fundamentally only Anglo-American or Western liberal ideals that have been—substantially_popularised only in the post-war years, conceptions of the Rule of Law cannot effectively be internationalised. This is because they are, essentially, not reflective of any situational context that can be considered truly international.

In other words, this geopolitical—and to some degree, temporal—bias means the modification of conceptions of the Rule of Law cannot affect a truly international solution to an international Rule of Law problem. In this respect, and in echoing the rationale outlined above for the differences in the international and domestic spheres, the problem and the solution can be seen to differ at the most basic level. In effect, as long as any formulation of the international Rule of Law seeks to rely on conceptions of the domestic Rule of Law, it will remain fundamentally parochial. In this sense, the pervasion of Western ideals suggests, like those of viewing the idea in context, an inability of conceptions of the Rule of Law to internationalise.

It is for the reasons outlined in this section that the premise undergirding the derivation of the international Rule of Law - that domestic conceptions can provide a source from which it is possible to derive the international Rule of Law — cannot hold. Accordingly, not only is derivation itself unnecessary, but also any discussion or debate regarding the appropriate way in which the 
international Rule of Law should be derived - that I will question in Section 4 - is, itself, unnecessary. Up to now I have argued that canonical conceptions that are frequently used as a basis for the derivation of the international Rule of Law are sufficiently different in relation to their contextual origins from the international context to be rendered conceptually irrelevant to the international Rule of Law. If my argument has been sufficiently convincing, then there is likely no point in reading any further. However, if that is not the case, I offer a further and related argument to augment my critique of derivation.

\section{Deriving the International Rule of Law: An Impractical and Unhelpful Exercise} (The Argument from Origins)

If you are still reading, it may be because my argument from context is, on its own, unconvincing. Accordingly, I bolster and extend my point by arguing that deriving the international Rule of Law from domestic conceptions is, notwithstanding my claim that derivation and the debate is unnecessary, in any event both impractical and unhelpful. It is so because the process of derivation requires the insertion of arbitrarily determined criteria and, in turn, this means we are taken no further in determining what the international Rule of Law is.

As noted above, whilst Hurd has stated direct derivation should not be engaged in, ${ }^{90}$ derivation is not completely shunned by all; it remains implicit across many approaches. I aggregate these approaches into two common methodologies relating to implicit derivation that could be described in this way:

(1) The deployment and amendment or augmentation of pre-existing Rule of Law conceptions ('the first common methodology'); and

\footnotetext{
${ }^{90}$ Hurd, 'The International Rule of Law and the Domestic Analogy' (n 4) 367; Hurd, 'The International Rule of Law' (n 4) 39-40.
} 
(2) The application of the Rule of Law to the international Rule of Law by co-identification of similar or related features across the two-international and domestic - concepts ('the second common methodology').

The first common methodology relates to the repurposing of a pre-existing Rule of Law laundry list of desiderata in an attempt to suitably internationalise the domestic concept. ${ }^{91}$ Many accounts have been subject to this process. As explained in the previous section, Dicey and Hayek's ideas are frequently repurposed: ${ }^{92}$ Dicey's Rule of Law formulation is commonly augmented with additional — substantive — desiderata that insert human rights into the internationalised concept; ${ }^{93}$ Hayek's formulation, or a combination of Dicey and Hayek's ideas, has also been repurposed to similar ends. ${ }^{94}$

In general terms, the second common methodology is derivative as the methodology suggests that the domestic Rule of Law account is used to provide a basic starting point which is then used to map the way to an international Rule of Law. The second common methodology has variously taken the form of: identifying what the international concept actually does, before comparing this to a predefined set of Rule of Law values; ${ }^{95}$ identifying a similarity of purpose across international and domestic Rule of Law ideas; $;^{96}$ or externalising core Rule of Law ideas onto the international plane..$^{97}$ In other words, the second methodology relates to attempts to identify similarities or commonalities in the content and meaning of the international concept by linking-in some way-domestic

\footnotetext{
${ }^{91}$ For an example of a stipulated custom laundry list, see Waldron, 'Are Sovereigns Entitled to the Benefit of the International Rule of Law?' (n 19). See also, Palombella (n 42).

${ }^{92}$ See, for example, Hurd, 'The International Rule of Law and the Domestic Analogy' (n 4); Chesterman (n 19); Crawford (n 41); McCorquodale (n 39); Palombella and Walker (n 34); Zifcak (n 37); Beaulac (n 41); Waldron, 'Are Sovereigns Entitled to the Benefit of the International Rule of Law?' (n 19).

${ }^{93}$ For the use of Dicey's formulation, see Hurd, 'The International Rule of Law and the Domestic Analogy' (n 4); Chesterman (n 19); Crawford (n 41); McCorquodale (n 39); Palombella and Walker (n 34). In relation to augmentation, see McCorquodale (n 39) 284. For Dicey's formulation, see Dicey (n 38).

${ }^{94}$ Chesterman (n 19) 343; Zifcak (n 37) 36; Beaulac (n 41) 8.

${ }^{95}$ Crawford (n 41).

${ }^{96}$ Mattias Kumm, 'International Law in National Courts: The International Rule of Law and the Limits of the Internationalist Model' (2003) 44 Va. J. Int'l L. 19; Waldron, 'Are Sovereigns Entitled to the Benefit of the International Rule of Law?' (n 19).

${ }^{97}$ Palombella and Walker (n 34).
} 
conceptions of the Rule of Law (in either their content or focus) with either the purpose or purported nature of the concept of the international Rule of Law. ${ }^{98}$ The adoption of some form of analogy would fall into this category. In order to draw a useful analogy between two things, firstly some details about those things must be known. ${ }^{99}$ However, in terms of the Rule of Law and the international Rule of Law analogising would require that we assume the two concepts share some common ground; but this goes to the heart of the definitional issue that we are trying to ascertain. In essence, and as I will outline in greater detail in a moment, to draw an analogy of this sort we must already know something about what we want to establish. In terms of defining the international Rule of Law, simply assuming the common ground necessary to analogise requires predetermination of crucial aspects of what we wish to achieve through the analogy. I expand on these issues below. As there is some overlap between them, I consider them according to the methodologies to which they could be seen to relate.

\subsection{Issues with both common methodologies.}

Most obviously, in circumstances where the content of the domestic concept of the Rule of Law is contested, the selection of any one laundry list of desiderata — or any customised list based directly on the same - can be criticised because this necessarily requires an element of arbitrary selection (of the relevant content of the laundry list.) Arbitrary inclusion of desiderata that are-for whatever reason - appealing is not necessarily incorrect or problematic. But including these desiderata under cover of the purported legitimacy provided by earlier accounts introduces substantial unclarity: Why this desideratum and not that one? What if Fuller's desiderata had been applied instead? Would the outcome differ if a 'thin' list was used? The ways in which questions like these, and hence unclarity, can arise are legion.

\footnotetext{
${ }^{98}$ For an account that assess whether the observable reality in the international sphere can result from the domestic Rule of Law, see Hurd, 'The International Rule of Law and the Domestic Analogy' (n 4); Hurd, 'The International Rule of Law' (n 4).

${ }^{99} \mathrm{I}$ am grateful to the anonymous reviewer for suggesting that I provide clarification in relation to this point.
} 
Further, any attempt to consider ideas of the international Rule of Law in the contemporary context through the application of Rule of Law ideas formulated before the conception of the modern operation of international law_-for example, through considering Rule of Law 'usual suspects' like Locke, Dicey, and even Hayek and Fuller-could be somewhat strained. In augmenting my argument from Section 3, the attribution of a meaning to what each thinker was actually doing - that goes substantially beyond the terms of reference for those thinkers - could be seen as being either anachronistic or something more than a simple application of that theory, masking, instead, the formulation of a substantially new idea behind a smokescreen provided by the earlier conception. This could relate to innovation in solving a new problem. If that is the case, it should be billed as such and not, as is often the case, as a modification of an existing idea. ${ }^{100}$

\subsection{Issues with the first common methodology.}

In considering Dicey and Hayek's ideas as frequently invoked foundational bases from which the international Rule of Law is derived, the selection of an additional substantive value to augment their domestic conceptions of the Rule of Law could be incompatible with the focus of those specifically formal conceptions. The most obvious example of this is the inclusion of human rights within the international Rule of Law. ${ }^{101}$ The mere inclusion of human rights in this way seems to do little to effectively and completely internationalise the domestic ideas to which they are attached. ${ }^{102}$ Augmentation in this way — or in any way that arbitrarily adds an additional facet to an original conception — seems an unsatisfactory way to provide a complete conception of an international Rule of Law when the subjects of augmentation are accounts that were specifically conceived as being domestic in their reach and application. This is the case as simply adding something that may be or

\footnotetext{
${ }^{100}$ For an argument relating to innovation in the formulation of Rule of Law ideas, see Burgess, 'Neglecting the History of the Rule of Law: (Unintended) Conceptual Eugenics' (n 45). I return to this idea by way of a broad-based solution in my conclusion below.

${ }^{101}$ McCorquodale (n 39).

${ }^{102}$ This seems to be especially the case when human rights, in the form that they are now universally acknowledged, would be fundamentally unrecognisable to early thinkers.
} 
is considered a universal should not be seen as being capable of universalising an idea that is, otherwise, geographically or socio-politically limited in its purview.

\subsection{Issues with the second common methodology.}

In seeking to identify any similarity of purpose across the two-international and domesticconcepts, there is an assumption that the conceptual content of the international Rule of Law must, in some way and to some extent, reflect the conceptual content of conceptions of the Rule of Law. Yet, even if common features can be identified, these need not be necessary elements. It seems eminently conceivable that a necessary element of the international Rule of Law-assuming, for the moment, such a thing exists - may not be a necessary domestic desideratum. For example, an obvious and necessary component of the international Rule of Law is that it be - in some way -international. This is, as has been mentioned, something that forms no necessary part of the domestic conceptions that are frequently applied to the task of derivation. This simple illustration suggests there is no direct reflection in the necessary components across (domestic and international) conceptions. ${ }^{103}$

Relatedly, it may be that certain domestic desiderata simply have no use or relevance in the international sphere. For example, the requirement that laws be known, or knowable, seems to be doing no work in an international community where states - as entities—are intimately involved in making law. ${ }^{104}$ Whilst this issue could be ameliorated through judicious selection of Rule of Law desiderata to highlight any commonality, this then falls foul of the first issue outlined above: cherry picking desiderata simply represents the arbitrary formulation of a concept based on a pre-conceived ideal of the international Rule of Law. This takes us no closer to clarity when ideas are shrouded under a cloak of assumed legitimacy provided by association with previous ideas. ${ }^{105}$

\footnotetext{
${ }^{103}$ Of course, this does not mean that there cannot be reflections of some aspects of the conceptions. It simply means that any reflection cannot be absolute and there must, therefore, be some other criteria for selection of the components that are deemed reflective.

${ }^{104}$ See Radin (n 9) 786; Fuller (n 14) 157. See also above note 82 and associated text.

${ }^{105}$ Again, this point is returned to and expanded upon in the conclusion below.
} 
A further assumption seems to be that conceptions of the Rule of Law can be modified into something that reflects - or is useful in the identification of - the international Rule of Law. (I challenged this assumption directly in Section 3.) Yet, it seems that even basic desiderata may meanand may need to mean — different things in the international and domestic concepts. This could result from the different institutions and subjects to which the international and domestic concepts could be seen to relate: Rule of Law predictability, for example, may not have the same meaning as international Rule of Law predictability. This assumption seems - in a similar way to the issue associated with the necessary conditions of each concept — to require that both 'ends' of the spectrum of international and domestic contexts be accurately known in order that any connection can be meaningfully inferred. But this seems to not reflect the agreed knowledge within the debate where the very idea of the content of the concepts of the Rule of Law or international Rule of Law is debated. To apply the second common methodology the inference of a meaningful connection is required; but this cannot follow—without arbitrariness - in terms where a contested idea is being used to derive the content of another contested idea, if the aim is to increase or ensure clarity in the outcome of the process.

The issues raised thus far relate to the arbitrary inclusion of additional meaning to original conceptions in a way that does not enhance clarity. This occurs because the reason and rationale for the use and application of various aspects of the Rule of Law require some form of arbitrary selection. In considering the fundamental nature of the issues that impact the two common methodologies outlined above - and where those methodologies encompass some of the most frequently cited ways in which the concept of the international Rule of Law is identified - there is, I suggest, a sufficiently strong reason to accept that the application of those methodologies (or similar forms of them) is both impractical and unhelpful in relation to bringing clarity to the international Rule of Law debate.

\section{Conclusions}

I have made two - interrelated - arguments as to why attempts to derive the international Rule of Law are unnecessary, impractical and unhelpful. First, in my argument from context, I argued that the 
basic premise that undergirds the potential derivation of the international Rule of Law-that conceptions of the Rule of Law can provide a source from which the international Rule of Law can be derived-cannot obtain as the context of the frequently invoked canonical ideas differs fundamentally from that of the international Rule of Law. As a result, both the act of derivation and any further discussion about how best to derive ideas of the Rule of Law are unnecessary. Second, in my argument from origins, where the aim is to attain clarity in the debate regarding the meaning and content of the international conception, I argued any attempt to derive a conception of the international Rule of Law is both impractical and unhelpful given the arbitrary inclusion of domestic conceptions' components.

The line I am advocating walking relates, I think, to more than a semantic difference; but it is, nevertheless, a fine one. The distinction between the application of a prior thinker's idea and the attribution of a more general idea that may be useful in a present context may, in fact, be on occasion so fine as to be almost inconsequential. However, there are circumstances where further clarity in relation to context and origins will be important. Clothing an arbitrarily formulated conception in the language of earlier canonical ideas — whilst potentially providing academic comfort and some degree of appropriated legitimacy - may mask the conceptions' true source. By making these arguments, I intend only to focus attention on the attainment of greater clarity in the ongoing debate regarding the nature of the international Rule of Law.

In many respects, I have provided a very negative account. I have sought to illustrate many of the problems that are associated with the-widely adopted-derivative processes of identifying the content and meaning of the international Rule of Law. At this very late stage, and by way of a mere suggestion, I want to demonstrate that all is not lost. There are ways-in addition to the methodologies adopted by Bishop and Hurd that I outlined earlier in this paper — to avoid the practices that I criticise. As noted above, innovation in terms of the Rule of Law and the international Rule of Law can, and should, take place. We must be aware of the context in which earlier accounts were provided. Aspects of what may otherwise seem to be useful conceptions may, when account is taken of context, need to be abandoned. This does not mean that the identification of a particular Rule of 
Law desiderata in the domestic sphere bars its use in the international arena. What it may, however, mean is that regardless of the apparent similarity of any solution that is sought in the international sphere, we avoid the-baked-in—academic temptation/requirement to refer back to the earlier account simply to justify the correctness or accuracy of the later account. It is this process of appealing to authority that leads to the derivative process which I have criticised. In short, if we have an idea about what the international Rule of Law is or should be, the argument should be made on that basis and not merely based on the simple adoption of prior domestic conceptions.

In suggesting that the international Rule of Law should be construed separately from the domestic Rule of Law, I do not argue that there is not, or cannot be, an international Rule of Law. What I do, however, propose is that attempts to define or construct the international Rule of Law should be an independent exercise; one that is conducted without seeking to derive the international conception from the domestic ideas that have proven increasingly popular in recent decades.

\section{Acknowledgements}

I have benefited enormously from comments and feedback from a number of individuals and groups. Thanks go to all participants where previous drafts were presented: the Harvard-Edinburgh Legal Theory Colloquium (February 2017); the Transnational Legal and Political Theory Conference, BarIlan University (May 2017); Governance, Legality, and Political Morality Beyond the State Conference, Burlington (September 2017); and at the Paul Scholten Centre for Jurisprudence, University of Amsterdam (October 2017). I am also grateful for the time and generosity afforded by the individuals that provided thoughts and comments outside of these venues: Richard Collins; Alon Harel; Ian Hurd; Martin Kelly; Chloë Kennedy; Lucas Miotto; Aoife O’Donoghue; Wendy Salkin; and Kara Woodbury-Smith. Additionally, I received a series of detailed and incredibly helpful reviewer comments which I have sought to both address and action. Notwithstanding all of these excellent comments, any errors or issues of unclarity which remain are solely attributable to me. 